\title{
The oceanic non-sulfidic oxygen minimum zone: a habitat for graptolites?
}

\author{
WILLIAM B. N. BERRY, PAT WILDE AND MARY S. QUINBY-HUNT
}

\begin{abstract}
Berry, W. B. N., Wilde, P. and Quinby-Hunt, M. S.: The oceanic non-sulfidic oxygen minimum zone: a habitat for graptolites? Bull. geol. Soc. Denmark, vol. 35, pp. 103-114. Copenhagen, July 1 st, 1987.

The denitrified low oxygen zone in Early Paleozoic oceans is proposed as a potential habitat of planktic graptolites. Modern analogs of this zone are found in the eastern tropical Pacific (ETP) and in the northern Arabian Sea as shallow regions, up to a 100 meters thick, at the top of the pycnocline. There, oxygen is low or undetected and hydrogen sulfide has not been found. In modern oceans, denitrification regions are limited vertically and horizontally as oxygen is replenished from below by ventilated deep waters. In the Early Paleozoicocean, the denitrification layer would be global due to poor deep ventilation. It would be transitional between oxygenated surface waters and toxic sulfide-rich water. Many branched graptolites could have evolved when the denitrified waters were in or close to the photic zone, feeding on the abundant phytoplankton attracted to both light and nutrients. As this zone sank below the photic zone, graptolites who developed planktic mode of life could have migrated daily toward the food supply, similar to euphausiids in the modern ETP. Thus the changes in graptolite rhabdosomes from pendent to scandent and from many branched to biserial and uniserial are suggested as adaptations to assist vertical migration and feeding. With the continued ventilation of the oceans and the shrinking of the denitrified layer, graptolite extinction could have resulted as a combination of reduction in food supply and living space, increased predation from the then evolving fish and ammonites, and competition in the zooplankton niche from smaller (less visible) and more motile forms.
\end{abstract}

William B. N. Berry, Pat Wilde and Mary S. Quinby-Hunt. Department of Paleontology, Marine Sciences Group, University of California, Berkeley, CA 94720, USA, August 29th, 1985.

\section{Introduction}

Bulman (1970:V91) observed that graptoloid graptolites occur predominantly in dark mudstone and shales that are "devoid of almost any other fossils, and that this occurrence constitutes the 'graptolite facies"'. Erdtmann (1982) pointed out that the preservation in graptolites of delicate peridermal structures suggests that both the living conditions and their sites of fossilization were removed from vigorous wave action and from highly oxygenated bottom waters which would have supported active predators and scavengers. This view is supported by the evidence that black graptolitic shales and mudstones commonly are characterized by finescale laminations, the absence of evidence of bioturbation, and locally abundant pyrite (Pettijohn, 1975:282). Bulman (1970), in his analysis of the environmental conditions under which the "graptolite facies" accumulated, suggested that "the essential condition is the complete lack of bottom circulation so that dissolved oxygen, soon exhausted, cannot be re- plenished; while a high proportion of decaying organic matter may be contributed by animal and plant remains falling from superficial aerated layers". Bulman (1970:V93) concluded that "it is a safe generalization that typical graptolite shales represent conditions more or less inimical to bottom life, and that graptolites owe their distinctively wide geographic distribution to their superficial drifting mode of life". This view concerning graptoloid graptolite mode of life and occurrence has been accepted since originally proposed by Hall (1865). The available evidence from graptoloid graptolite occurrences suggests that these graptolites were most abundant in warm, perhaps tropical to sub-tropical, waters and that most appear to have floated in waters over the outer parts of the shelves or platforms (Berry, 1979).

Recently, Berry and Wilde (1978) and Wilde and Berry $(1982,1984)$ applied fundamental concepts of physical and chemical oceanography to distinguish the oceanic conditions which could lead to the development of widespread dark, organic-rich mudstones and shales typical of the graptolite facies discussed by Bulman (1970). 
They concluded that the Early Paleozoic oceans were anoxic beneath the suface wind-mixed and oxygenated layer during globally warm climates. During the Late Ordovician glacial interval and late Early Devonian cool climates, the waters below the pycnocline probably were ventilated by deep circulation driven by cold waters sinking at high latitudes similar to the circulation seen in the modern ocean. In their review of mechanisms that create anoxic conditions in the oceans, Demaison and Moore (1980) supported Berry and Wilde's (1978) view that the organic-rich black shales of the Early Paleozoic formed in anoxic waters beneath an aerated surface mixed layer.

Modern analogs of oceanic environments in which sediments similar to those of the graptolite facies could accumulate necessarily are limited in extent due to the well-ventilated and relatively rapid circulation in the present open ocean (Munk, 1966). Local anoxic conditions related to poor circulation are found in the Cariaco Trench, the Gotland Deep, and various fjords (Richards, 1965, Deuser, 1975, Glasshof, 1975).

There are, however, areas of the modern open ocean transitional between oxic and anoxic waters which may be analogs of the living conditions under which the graptolite biofacies developed. The assumption is made that many types of graptolites must have lived in the open ocean at a depth in close proximity to the zone of their fossilization. Modern transitional areas include two parallel lobes flanking the equator in the eastern tropical Pacific (ETP) and the northern Arabian Sea in the Indian Ocean, where the oxygen minimum zone is both shallow and oxygen values are very low to undetectable, when compared with the typical open ocean (fig. 1). Oceanic conditions in these modern warm seas include not only warm but also highly productive surface waters, a relatively steep and shallow pycnocline, and an oxygen minimum zone with oxygen values as low as $0.25 \mathrm{ml} / 1$ to undetectable (Brinton, 1980). The physical characteristics of the most extensive of such regions in the ETP have been described by Wooster and Cromwell (1958) and Wyrtki (1967). Unlike conditions in the Early Paleozoic ocean, the deep waters below the dysaerobic waters are well oxygenated so that the oxygen minimum zone is prevented from becoming anoxic by vertical advection of oxygen. The modern areas of declining oxygen values at shallow depths just below the surface mixed layer would be the analogs of the upper part of the Paleozoic water column above the anoxic zone.

\section{Chemical oceanography of the eastern tropical Pacific lobes}

"At low latitudes, the eastern Pacific Ocean is characterized by a permanent, often shallow, and geographically extensive oxygen minimum. The

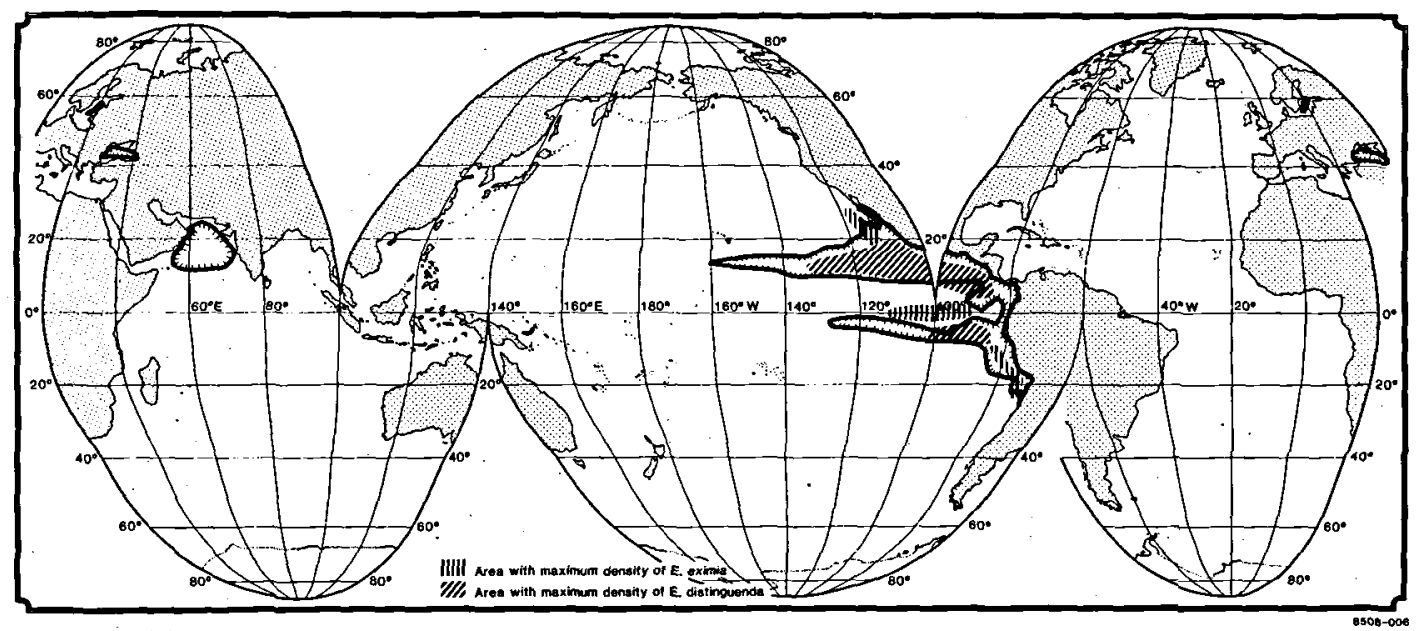

Fig. 1. Hachured regions show the distribution of modern marine waters with oxygen content less than 0.4 milliliters per liter (after Deuser, 1975). Characteristic species endemic to oxygen-poor waters in the eastern tropical Pacific (after Brinton, 1980). Projection is Goode's Homosline equal-area, copyright, University of Chicago. 
minimum is thickest, comes closest to the surface, and is most depleted of oxygen within two tongue-like projections lying north and south of the equator (Wyrtki, 1967). In regions of coastal upwelling, nearly anoxic water from this minimum can reach within a few meters of the surface" (Judkins, 1968). The value of oxygen falls so low that it is essentially undetectable in the core of the oxygen minimum zones in these waters (Wyrtki, 1967, Brinton, 1980). However, hydrogen sulfide has not been verified here (Anderson et al., 1982). Devol (1978) found that oxidation by oxygen ceases in sea water at oxygen values below $0.22 \mathrm{ml} /$. This means there is a zone in which oxygen can be detected but is not used chemically as an oxidant. Thermodynamically, (Stumm and Morgan, 1970; Curtis, 1983: 271273) oxidation of organic matter will continue below such oxygen values by reduction of nitrate. As oxygen diminishes from the margins of the oxygen-deficient water to its core, nitrate released by oxidation of organic matter in the surface aerated mixed layer is reduced to nitrite and molecular nitrogen (Richards, 1965), Goering, 1968, Anderson, 1982). After the depletion of nitrate, the denitrification zone (Anderson et al., 1982, Mullins, Thompson, McDougall and Vercoutere, 1985) would be followed in the thermodynamic sequence by a zone in which nitrite is reduced. In the ETP, however, this step does not occur because oxygen is advected from below (fig. 2) reoxidizing nitrite to nitrate and replacing nitrate as the oxidizing agent of organic matter. Anderson (1962) suggested that nitrite is oxidized back to nitrate, primarily by bacterial action, at the top of the oxygen minimum zone. The presence of active nitrogen compounds which inhibit sulfate reduction and the generation of hydrogen sulfide explains the general absence of toxic hydrogen sulfide in the oxygendeficient waters of the modern open ocean.

\section{Biological activity in modern oxygen minimum zones}

\section{Phytoplankton}

Mullins et al. (1985:491) stated that: "little is known about biogeochemical boundary transitions from well-oxygenated to oxygen-deficient environments". Their study of the oxygen minimum zone produced by local coastal upwelling off central California near Point Sur revealed "that the edges or boundaries of the oxygen minimum zone are 'hot spots' of increased biogeochemical activity". Holligan, Williams, Purdie and Harris (1984) cite dinoflagellate blooms in similar types of waters on both the Peruvan and West African coasts. Anderson (1982) and Anderson et al. (1982) discussed the chemistry of

\section{Oxygen Minimum Zone Off Peru}

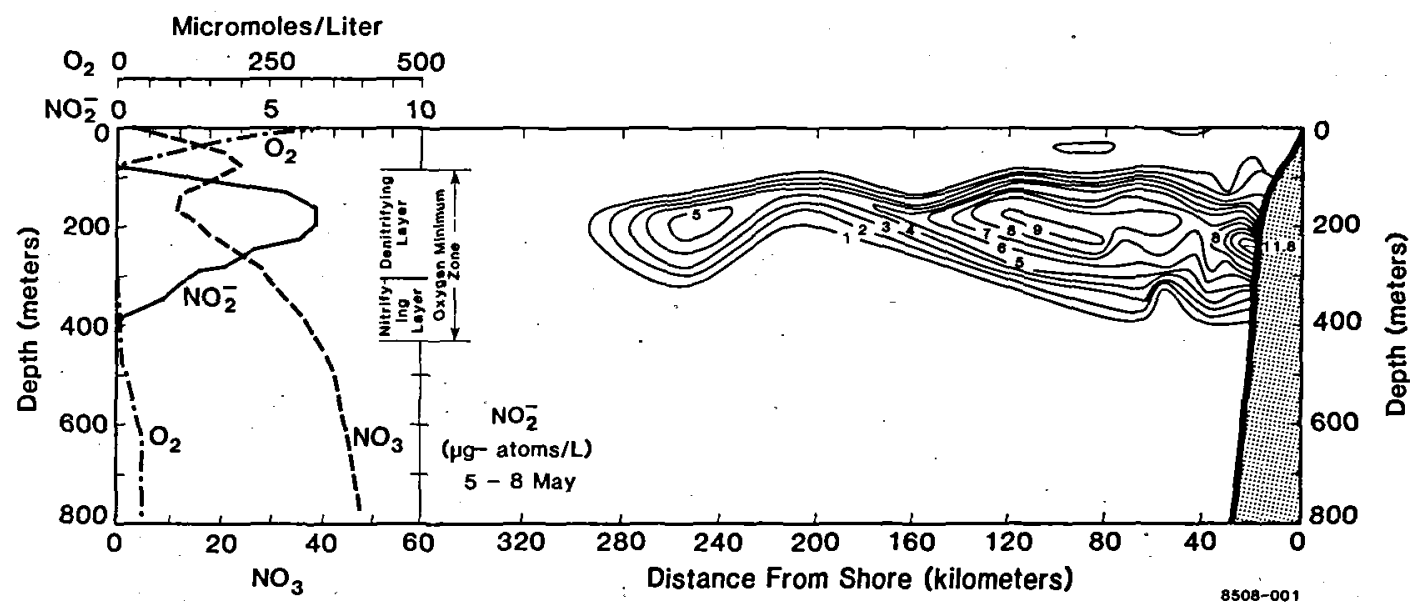

Fig. 2. Oxygen, Nitrate, Nitrite profiles in the oxygen minimum zone and adjacent waters in the eastern tropical Pacific off Peru. Values in micromoles per kilogram (after Anderson et al., 1982). 
the nitrite-oxygen interface at the top of the ETP oxygen minimum zone. Based on that data, Mullins et al. (1985) suggest that bacteria in the oxygen minimum zone "reduce biologically usable nitrate to nitrate and part of the nitrite to molecular nitrogen via the denitrification process". Anderson (1982) indicated that some usable nitrate will diffuse away from the oxygen minimum waters to be oxidized back to usable nitrate at the oxygen-minimum zone interface with the mixed layer. This nitrogen recycling results in an increase in the amount of biologically useful: (1) nitrate and nitrifying bacteria in the boundary of the oxygen minimum zone and (2) dinitrifying bacteria in the core of the oxygen-deficient water. Mullins et al. (1985) concluded that such waters "may be preferred sites of increased biological activity because of greater nutrient concentrations plus larger food supplies in the form of bacteria". This conclusion is consistent with that of Holligan et al. (1984) who suggested that high rates of nitrogen availability results in dinoflagellate blooms; and it is corroborated by the presence of bacterial mats at the oxygen poor watersediment interface under coastal upwelling systems.

Eppley, Holm-Hansen and Strickland (1968) found that certain species of the dinoflagellate Gonyaulax migrate vertically daily to seek ammonia at depth in preference to the more nearsurface available nitrate. Holligan et al. (1984) noted that zooplankton may play a significant role in recycling ammonia at depth. They found in coastal waters off west Africa that zooplankton contribute more than forty percent of the ammonia required by phytoplankton. Thus, data from oxygen minimum zone under upwelling regions in the modern ocean, indicates that nitrogenous compounds forming at the margins of oxygendepleted waters may be an important source of nutrients and contribute to even higher rates of biological productivity in these waters.

\section{Zooplankton and Nekton}

Brinton (1980) reviewed euphausiid distribution in the ETP, drawing attention to certain species that are endemic to these waters as well as to species that occur in waters of lowest oxygen content. Both Brinton (1962, 1980) and McGowan (1971) suggested that the zooplankton in the ETP constituted a distinct biogeographical provincial fauna within the Pacific Ocean. Brinton (1962, 1980) cited particularly four euphausiid species that are endemic to these waters. Ebeling (1962) indicated that a distinctive fish fauna inhabits ETP waters, and suggested that the ETP fish fauna comprises one of the four major zoogeographic divisions of fish in warm tropical waters. Brinton (1980:126) suggested that the ETP does comprise a distinctive biogeographical province because of its "temporal stability in the extreme environmental features combined with high nutrient availability particularly where the thermocline ridges".

Brinton (1980) emphasized the importance of euphausiids as constituting the numerically most abundant zooplankton in ETP waters. This confirmed the work of Blackburn, Laurs, Owen and Zeitschel (1970) who found euphausiids to be the most prominent zooplankton in their examination of tuna foraging in ETP waters. Holmes, Schaefer and Shimada (1957), Reid (1962) and Banse (1964) reviewed primary productivity and faunal occurrence data for ETP waters and concluded that both phytoplankton and zooplankton were abundant in them. Organisms seem to occur abundantly in these waters as a consequence of both high temperatures and high nutrient availability.

Longhurst (1967) analyzed zooplankton that occur in waters at the northen margin of the ETP. In that area, whole populations of copepods and euphausiids migrate vertically daily, spending the daytime in waters with an oxygen content of about $0.25 \mathrm{ml} / \mathrm{l}$. Brinton (1980:191) found some species spend most of their lives in oxygen-poor waters. Other species live almost exclusively on the margins of the oxygen-poor zones. Even other species concentrate symmetrically above or below oxygen-deficient waters. Brinton (1980) described two modes of euphausiid adaptation to the presence of the oxygen-poor water: active vertical migration in and out of oxygen-poor waters, and avoidance of the oxygen-poor waters by non-migrators. The euphausiid species that Brinton (1980:180) "designated 'equatorial endemics, ETP adapted" "spend the day at depths of 200 to 400 meters in oxygen-deficient waters, but at night, they move vertically upward as much as 300 meters to alleviate the oxygen debt they incurred during the day. Eupausia distinguenda is 
especially abundant and localized is oxygen-deficient waters (fig. 1). Certain species that live for considerable periods of time in oxygen-deficient waters have been studied in the laboratory. Teal and Carey (1967) showed that Euphausia mucronata could respire in waters in which oxygen is barely detectable. Studies of the mysid crustacean Gnathophausia ingens (Childress, 1968) indicated that this planktic predator could regulate its oxygen consumption so effectively that it can swim in waters with oxygen values as low as 0.14 to $0.20 \mathrm{ml} / \mathrm{l}$.

\section{Benthic organisms}

Figure 3, based on modern observations in the southern lobe of the ETP off Peru and Chile (Coles, in Menzies, George and Rowe, 1973:145), shows the area of intersection of the denitrification zone and the sea floor is inhabited by holothuroids, snails, and alcyonarians. Gallanos (1963) characterized this area as "semiabiotic" with no wholly infaunal life and with sediment containing hydrogen sulfide and fish scales and bones. The largest benthic biomass, here, was $49.46 \mathrm{~g} / \mathrm{m}^{3}$ at the top and $28.5 \mathrm{~g} / \mathrm{m}^{3}$ at the base of the oxygen minimum zone, with a minimum value of $6.5 \mathrm{~g} / \mathrm{m}^{3}$ at the core of the oxygen-depleted zone (Menzies et al., 1973:66). This parallels the relatively high organic concentration at the boundary of the oxygen minimum zone noted in the phyto- and zooplankton distribution.

Douglas (1981) and Mullins et al. (1985) found the sea floor intersected by the less extreme oxygen-minimum zone under the area of coastal upwelling along the central California coast to be inhabited by polychaetes and bolivined foraminferans. Douglas (1981) noted that the bolivinids living on "bottoms where oxygen values are below $0.3 \mathrm{ml} / 1$ " are large, have thin-walled tests, and posses a high surface to volume ratio. Govean (1980) recorded the presence of similar bolivinids in dark, organic rich shales of the Miocene Monterey Formation in California.

\section{Chemical oceanography in the Lower Paleozoic}

Today, the denitrification zone is found off shores with steep slopes (fig. 2). Consequently, the interval of intersection of the denitrification

\section{Distribution of Benthic Organisms with Depth in Peru-Chile Trench}

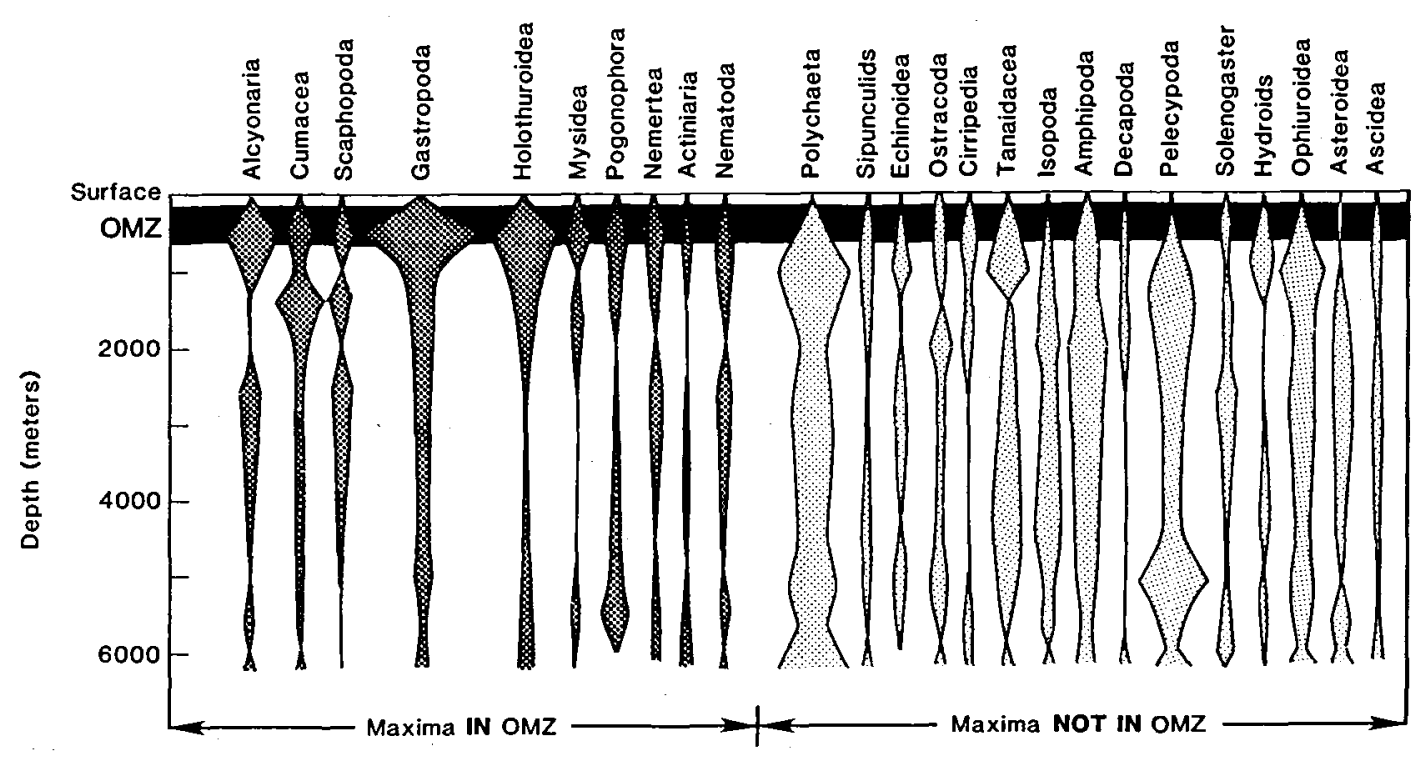

8508-002

Fig. 3. Faunal distribution with depth in the eastern tropical Pacific off Peru (after Coles, in Menzies et al., 1973). Width of pattern of each group represents relative abundance with depth. Oxygen minimum zone (OMZ) shown in black. 
zone with the sea floor is narrow. In the Early Paleozoic, the denitrification zones and subsequent anoxic zones, including sulfate reduction zones, could have spread widely over the outer margins of the continental shelves (fig. 4). Accordingly, the area of intersection could have extended into relatively near shore, shallow settings. Berry and Wilde (1978), Erdtmann (1982), and Wilde and Berry $(1982,1984)$ suggested that the expansion of anoxic waters during warm, equable climatic intervals could explain the global extensiveness of the graptolite facies. A position of the top of the denitrification zone at about 100 meters beneath the oxygenated mixed-layer also would explain the absence of nearly all shallow water dwelling organisms in graptolite-bearing shales. With no deep ventilation then, the proximity of the denitrification zone to the zone of sulfate reduction could explain the preservation of delicate graptolitic rhabdosomal structures. With such anoxic stratification of the ocean, dead graptolites particularly those in or near the denitrification zone, would sink into the lower anoxic zones which would have been devoid of all but bacterial scavengers. As Judkins (1980) noted, in the ETP during upwelling, essentially anoxic waters almost reach the surface. Upwelling from anoxic zones in the Paleozoic ocean containing ammonia, methane, and hydrogen sulfide, are likely to have produced mass kills in superjacent waters. Such toxic upwelling may be reflected in the geologic record by local abundance of graptolite rhabdosomes concentrated on single bedding planes.

Erdtmann (1982) identified three graptolite sedimentary facies for dictyonemids. These facies may reflect the intersection of the anoxic zones with the sea floor (Fig. 4). Erdtmann's (1982) facies and their anoxic zonal equivalents are: (1) glauconitic - denitrification layer - life assemblage (benthic forms); (2) brown bituminious non oxic and non sulfidic layer - death assemblage; and (3) black shale/pyritic - sulfidic layer death assemblage.

\section{Potential biotopes for graptolites}

The patterns in zooplankton occurrence cited by Brinton (1980) within and in the vicinity of the oxygen-poor waters of the ETP may provide clues to planktonic graptolite habitats. Graptolites could have been the resident zooplankton in waters similar to those of the modern ETP. The major difference would have been that in the Lower Paleozoic due to the residual anoxic layer (Berry and Wilde, 1978), waters would have been anoxic below the oxygen-depleted (denitrification) zone now found in the core of the oxygen minimum zone in the ETP.

The planktic graptolites could have been segregated in patterns similar to those of the zooplankton of the ETP. Some graptolites apparently lived in the mixed layer as they are found in association with benthic invertebrates in the shallow shelf shelly biofacies. Other graptolites may have lived in the base of the mixed layer, in the region of declining oxygen values above the denitrification zone. A few may have lived exclusively in the denitrification zone. Brinton (1980) suggested that the long-term stability of conditions found in the ETP, such as high productivity and a shallow pycnocline resulting from essentially permanent planetary upwelling and fixed circulation patterns astride the equator, led to the development of the unique zooplankton found there. The equatorial location is also relatively insensitive to seasonal and long-term temperature fluctuations observed in higher latitudes. Physically and chemically similar waters are found elsewhere, such as in the northern Arabian Sea (Qasm, 1982). However, such waters lack the distinctive and abundant zooplankton found in the ETP (Brinton, 1980). This may be caused by the seasonality of oceanographic conditions and thus the lack of annual stability in the nutrient supply.

The mode of life of some planktic graptolites has been postulated by interpretations of rhabdosomal structures. Apical vesicles on Dictyonema flabelliforme have been considered as buoyancy structures (Störmer, 1933, 1935, and Bulman and Störmer, 1971). Kirk (1979) proposed that vane-type structures seen in certain biserial scandent forms are used for active vertical mobility. Crowther and Rickards, 1977) suggested, however, a more passive role for such structures. The modern tunicate Pyrosoma spinosum moves laterally by co-ordinated pulses of feeding currents along the colonial tube (Grace, 1971). Some graptolites might have functioned similarly. The combination of positive buoyancy 


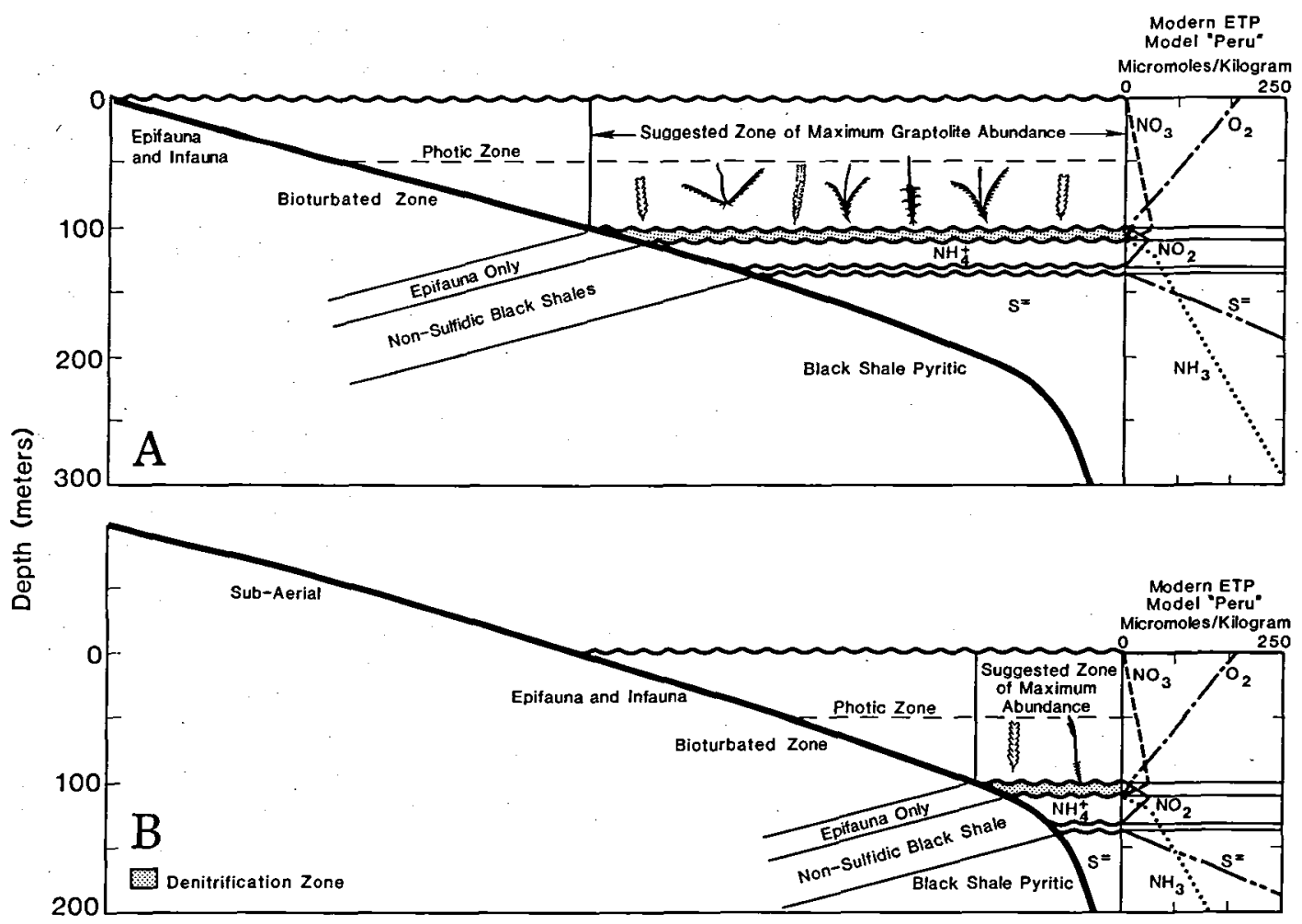

Fig. 4. Proposed relationships in the Late Ordovician among planktic graptolitic biotopes, chemical oceanography and marine sediments. Model values use modern surface conditions in the eastern tropical Pacific off Peru, but with no deep ventilation. A. Proposed conditions for warm climates or high stands of sealevel. B. Proposed conditions for cold climates in the terminal Ordovician or low stands of sealevel.

structures with pulsative motive power would have the potential for vertical mobility similar to that shown today by the deep scattering layer organisms (Hersey and Backus, 1962).

\section{Graptolite adaptation to the denitrification zone}

Comparison of graptolite occurrences and inferred conditions for the graptolite biofacies with modern physical, chemical, and biological oceanographic analogs suggests that graptolites lived closely associated with oxygen-deficient or depleted zones similar to those found in the modern ETP. In addition, oxygen-deficient waters under seasonal upwelling areas, such as off California, offer potential analogs for the development of non-tropical species. Today, these waters contain increased concentrations of reduced nitrogen compounds such as ammonia which are preferred by phytoplankton over more oxidized forms of nitrogen (Eppley, Rogers and McCarthy, 1969). These waters contain abundant zooplankton populations presumably feeding on the large phytoplankton floras. During the warm and equitable climates of the Early and Middle Ordovician and most of the Silurian, conditions in the mixed layer similar to those found in the modern ETP were widespread. The global extent and long duration of these conditions (tens of millions of years) provided a longterm stability for adaptation and development of distinct graptolite faunas. Certain graptolites could have provided ammonia for recycling by phytoplankton like modern euphausiids (Eppley et al., 1969; Holligan et al., 1984). Other graptolites may have simply grazed the phytoplankton localized there.

During the Early Paleozoic, in the base of the mixed layer, the occurrence of transitional anoxic oceanic layers between the surface well-oxygenated waters and deeper anoxic and sulfidic waters 
would have inhibited respiring infaunal organisms by the development of toxic sulfidic conditions a few millimeters beneath the water-sediment interface. The rapid decline in the redox potential in sediment results from a greater content of organic matter in sediment than in the water column (see Frolich, Klinkhammer, Bender, Luedtke, Heath, Cullen, Dauphin, Hammond, Hartman and Maynard, 1979 and Berner, 1980 for the redox sequence in marine sediments). This is caused in oxygen-depleted waters by the short residence time in the water column of much of particulate organic matter (Smayda, 1970, Shanks and Trent, 1980) and the decreased oxidative capacity of ions below oxygen in the thermodynamic sequence. Such conditions are seen today off Peru in the southern portion of the ETP, where the majority of the benthic organisms found in the zone of denitrification are infaunal sestonophages (Menzies et al., 1972:149).

In a similar zone in the Early Paleozoic where bottom life was limited to the sediment surface, benthic organisms that had planktic larval stages would have had a greater opportunity for dispersal, settlement and survival. Those forms that developed some form of air sac or bladder would have had the additional potential for regulated vertical migration. Dictyonema flabelliforme may be an example of such adaptation from an initial benthic mode of life. The graptolites living almost exclusively in the oxygen-depleted zone also avoided active respiring predators, who were restricted to oxygen-rich waters. However, such graptolites were more prone to being killed by upwelling of toxic waters into the denitrification layer.

Graptolites would have responded to changes in depth and thickness of the denitrification zone through time. During long-term warm climates in the Paleozoic, the denitrification zone, which is limited in the modern ocean, would have been global in extent as a transition redox zone between oxygen-rich surface layers and anoxic waters at depth. Due to higher stands of sea-level in non-glacial times, a larger portion of the shelf would be overlain by this zone, even if the bottom waters were sulfidic (fig. 4). During cool or glacial intervals such as in the Late Ordovician, the oxidation state would be modified and the potential for oxygen aeration of deep waters existed. Wilde and Berry (1984) suggested that even oceanic overturn was possible at either the beginning or end of a glacial interval as a result of shift in source and density of water masses. An oceanic overturn, particularly at the beginning of a glacial episode after a long period of stable deep anoxic conditions, could bring toxic sulfidic waters into the less anoxic zones and even into the base of the mixed layer. During cool or glacial intervals, even whithout destabilization of the oceanic density structure, advection of cooler more oxygen-rich waters from depth and higher latitudes would modify both the temperature and redox state in the water column where graptolites lived.

\section{Influence of a habitat in the denitrification zone on graptolite evolutionary trends}

If, as is suggested here, graptolites were linked closely to and probably originated in oxygendeficient, denitrification zone waters similar to those of the modern ETP, then certain trends in graptolite evolution may be related to adaptations of the graptolite colony to changes in depth and thickness of the denitrification zone during the Early Paleozoic. Large, many-branched rhabdosomes would have been well-adapted to the environmental conditions resulting from the presence of the denitrification zone within the photic zone. Extensive phytoplankton, which would have occurred as a result of the coincidence of light availability and abundant nutrients, would have been available to support the numbers of zooids in multiramous rhabdosomes. Increased solution of oxygen in sea water and more rigorous circulation during cool to cold climatic intervals would have driven the denitrification layer below the photic zone, except in regions of poor circulation such as those of the modern Arabian Sea and ETP. Sinking of the denitrification zone would have diminished the areal extent of that zone and moved the preferred living conditions of graptolites to a position below the waters in which their food organisms lived. Under such circumstances, pendent and branched rhabdosomes would have difficulties in food gathering. They would have depended primarily upon materials raining down from waters 
above, yet most zooids faced downward. The scandent colony organization, however, provided colonies living in waters below those in which their food supply existed with zooids facing upward to more effectively gather food as it descended. Also, scandent organization streamlined colonies and made vertical motility easier. Branched, non-scandent colonies would have been more successful when warm climates periodically returned and the denitrification zone expanded to come nearer to the photic zone. The gradual elimination of pendent forms would have been a consequence of climatically induced ventilation of the anoxic layer (Berry and Wilde, 1978) and resultant continued lowering of the top of the denitrification zone. Adaptations such as branched, uniserial rhabdosomes (in cyrtograptids, for example) may have developed to spiral through the water to sample larger parcels of water than colonies that simply moved vertically. The gradual disappearance of biserial scandent colonies after the uniserial scandent forms appeared suggests that the uniserial scandent colony organization could have been more effective in vertical migration. Possibly, many uniserial scandent taxa migrated daily from oxygen-deficient into oxic waters as do certain modern euphausiids. In the present ETP, tuna tend to congregate and feed on abundant euphausiids at the boundaries of the oxygen minimum zone. By analogy, active respirors, such as fish and ammonites, evolving during the early part of the Devonian, may have been attracted to large, visible graptolite colonies as a source of food. As climates cooled in the latter part of the Early Devonian, graptolites would have been forced to spend more time in aerated waters of the mixed layer, thus making predation more likely. Modern zooplankton include numbers of copepods and euphausiids that are better adapted for mobility than were the graptolites. The combination of a diminishing living space, increasing predation, and competition in the zooplankton niche from smaller or more motile organisms such as the dacryoconarids, all contributed to the eventual extinction of the graptolites.

\section{Summary}

Shallow oxygen-deficient waters beneath oxic mixed-layer waters in modern oceans provide a potential analog of graptolite living conditions in the Paleozoic. The most extensive of these modern oceanic environments, the waters of the Eastern Tropical Pacific, have been stable long enough to have developed a characteristic endemic fauna. The animals of this fauna have developed adaptations for survival under conditions of low to no oxygen availability and to feed on phytoplankton that use reduced nitrogen compounds concentrated in these waters. As such waters were more wide-spread in the Early Paleozoic than today, such exclusively Paleozoic organisms as the graptolites, who occupied the zooplankton niche, may have lived in or adjacent to similar waters. Such a biotope for planktic graptolites would explain their common fossil occurrence (1) in clusters on single bedding planes and (2) without accepted aerobic faunas, both resulting from local upwelling from toxic, anoxic layers below which did not reach the surface aerated waters. Changes in the graptolite colony, from many to few branches and from pendent to scandent forms may be a reflection of adaptation to life in the denitrification zone as it sank to greater depths as a consequence of both surface and deep ventilation with time. The change from biserial to uniserial scandent forms may have permitted these graptolites to migrate vertically to more effectively feed and respire in the oxic layer, while enjoying the protection from respiring predators by descending into the denitrification zone. Greater residence time of graptolites in the oxic mixed layer due to the sinking of the denitrification zone would have exposed them to predation by evolving fish and ammonites and competition from smaller or more active zooplankton, thus resulting in extinction of the group in the Early Devonian.

Acknowledgements. The authors would like to thank the various anonymous reviews for their thoughtful and useful comments. M. A. Krup did her usual outstanding job on the illustrations and in the preparation of both the conference paper and slides and this paper. This report is contribution MSG-85014 of the Marine Sciences Group, University of California. 


\section{Dansk sammendrag}

Den nitrogen-fri, iltfattige zone i tidlige paleozoiske oceaner foreslås som en mulig niche for planktoniske graptolitter. Nutidige analoger til denne zone findes i det østlige tropiske Stillehav og $i$ den nordlige Persiske Golf $i$ form af lavere vand med dybder op til ca. $100 \mathrm{~m}$ i den øvre del af densitets-gradienten. I dette interval er iltindholdet lavt eller manglende men er ikke lavt nok til at der eksisterer svovlbrinte. I nutidige have er de kvælstoffattige regioner afgrænsede horisontalt og vertikalt, idet ilt bliver tilført nedefra fra dybere vandmasser. I tidlig paleozoikum kan man antage at det kvælstof-fattige lag var tilstede $i$ hele verden p.g.a. dårlig ventilation af de dybere vandmasser. Det kunne fungere som overgangs-laget mellem det iltholdige overfladevand og det giftige sulfid-holdige varid. Mange grenede graptolitter kunne have udviklet sig når de kvalstof-fattige oceandele lå $i$ den fotiske zone eller nar ved denne, idet det ville tillade dem at leve af rigeligt phytoplankton, der ville blive tiltrukket af både lys og rigelige naringsstoffer. I takt med at zonen sank under den fotiske zone kunne de graptolitter, der havde udviklet planktonisk levevis, have foretaget daglige vertikale vandringer $i$ lighed med euphaside krebs i nutiden. Man kunne derfor trenke sig at udviklingen frà f.eks. grenede former henimod to-radede eller en-radede kunne vare tilpasninger, der ville lette disse daglige vandringer. Med den tiltagende udluftning af oceanerne og dermed indskrupningen af det kvalstof-fattige lag kunne dette have ledt til uddøen af graptolitterne som en konsekvens af reduceret miljø og nedsat næringsmangde ligesom forøget pres fra fisk og ammonitter kan have spillet en rolle i samme retning. Endelig må man overveje effekten af mindre og ikke så iøjnefaldende plankton-arter, som kan have givet konkurrence.

\section{References}

Anderson, J. J. 1982: The nitrite-oxygen interface at the top of the oxygen minimum zone in the eastern tropical North Pacific. Deep-Sea Res. 29: 1193-1201.

Anderson, J. J., Okubo, A., Robbins, A. S. and Richards, F. A. 1982: A model for nitrite and nitrate distributions in oceanic oxygen minimum zones. Deep-Sea Res. 29: 11131140.

Berner, R. A. 1981: A new geochemical classification of sedimentary environments. J. Sed. Pet. 51: 359-365.

Berry, W. B. N. 1962: Graptolite occurrence and ecology. $J$. Paleont. 36: 695-718.

Berry, W. B. N. and Wilde, P. 1978: Progressive ventilation of the Oceans - An explanation for the distribution of the Lower Paleozoic black shales. Am. J. Sci. 278: 257-275.

Blackburn, M., Laurs, R. M., Owen, R. W. and Zeitschel, B. 1970: Seasonal and areal changes in standing stocks of phytoplankton, zooplankton and microneckton in the eastenn tropical Pacific. Mar. Bio. 7: 14-13.

Blackburn, T. H. 1983: The microbial nitrogen cycle. In: Krumbein, W. W. (ed.): Microbial Geochemistry. Blackwell Scientific Publications, Oxford, p. 63-89.

Brinton, E. 1962: The distribution of Pacific euphausiids. Scripps Inst. Oceanogr. Bull. 8: 51-270.

Brinton, E. 1980: Distribution of euphausiids in the eastern tropical Pacific. Prog. Oceanogr. 8: 125-189.

Bullman, O. M. B. 1970: Treatise on Invertebrate Paleontology, Part V. (Revised) Graptolithina. Geol. Soc. Am. $163 \mathrm{p}$.

Bullman, O. M. B., and Störmer, L. 1971: Buoyancy structures in thabdosomes of Dictyonema flabelliforme (Eichwald). Norsk. Geol. Tids. 51: 25-31.
Childress, J. J. 1968: Oxygen minimum layer. Vertical distribution and respiration of the mysid Gnathoplausia ingens. Sci. 160: 1242-1243.

Crowther, P. R. 1978: The nature and mode of life of the graptolite zooid with reference to secretion of the cortex: Acta Paleontologica Polonica 24: 473-479.

Curtis, C. D. 1983: Microorganisms and diagenesis of sediments. In: Krumbein, W. W. (ed.): Microbial Geochemistry. Blackwell Scientific Publications, Oxford, p. 263286.

Demaison, G. J. and Moore, G. T. 1980: Anoxic environments and oil source bed genesis: Am. Assoc. Petrol. Geol. Bull. 64: 1179-1209.

Deuser, W. G. 1975: Reducing Environments. In: Riley, J, P. and Skirrow, G. (eds.) Chemical Oceanography, 2nd ed. Academic Press, New York, 3: 1-37.

Devol, A. H. 1978: Bacterial oxygen kinetics as related to biological processes in oxygen deficient zones of the oceans. Deep-Sea Res. 25: 137-146.

Douglas, R. G. 1981: Palecology of continental margin basins. A modern case history from the borderland of Southern California, In Douglas, R. G., Colburn, I. P. and Gorsline, D. S. (eds.) Depositional systems of active continental margin basins. SEPM Pacific Section Short Course Notes, 121-156.

Ebeling, A. W., 1967: Zoogeography of tropical deep sea animals. Studies in Tropical Oceanography, 5: 593-613.

Eppley, R. W., Holm-Hansen and Strickland, J. D. H. 1968: Some observations on the vertical migration of dinoflagellates. J. Phycol. 4: 333-340.

Eppley, R. W., Rogers, J. N. and McCarthy, J. J. 1969: Half saturation constants for uptake of nitrate and ammonium by marine phytoplankton. J. Phycol. 5: 912-920.

Erdtmann, B.-D. 1982: Palaeobiogeography and environments of planktic dictyonemid graptolites during the earliest Ordovician. In: Bassett, M. G. and Dean, W. T. (eds.): The Cambrian-Ordovician boundary: sections, fossil distributions, and correlations. National Museum of Wales, Geological Series No. 3, 9-27.

Froelich, P. N., Klinkhammer, G. P., Bender, M. L., Luedtke, N, A., Heath, G. R., Cullen, D., Dauphin, P., Hammond, D., Hartman, B. and Maynard, V. 1979: Early oxidation of organic matter in pelagic sediments of the eastern equatorial Atlantic: suboxic diagenesis. Geochim. Cosmochim. Acta 43: 1075-1090.

Gallardo, A. 1963: Notas sobre la densidad de la fauna bentonica en el sublitoral del norte de Chile. Gayana Zool. 8: 3-15.

Goering, J. J. 1968: Denitrification in the oxygen minimum layer of the eastern tropical Pacific Ocean: Deep-Sea Res., 15: $151-164$.

Grace, R. V. 1971: Giant Pyrosoma seen in New Zealand seas. Australian Natural History 17: 118-119.

Govean, F. M. 1980: Some palecological aspects of the Monterey Formation, California. Ph.D. Thesis, University of California, Santa Cruz, 279.

Hall, J. T. 1865: Graptolites of the Quebec group. Figures and descriptions of Canadian organic remains. Cand. Geol. Surv. Dec. 2: $151 \mathrm{p}$.

Hashimoto, L. K., Kaplan, W. A., Wofsy, S. C. and McElroy, M. B. 1983: Transformations of fixed nitrogen and $\mathrm{N}_{2} \mathrm{O}$ in the Cariaco Trench. Deep-Sea Res. 30: 575-590.

Holligan, M. R., Williams, P. J. Le B., Purdie, D., and Harris, R. P. 1984: Photosynthesis, respiration and nitrogen supply of plankton populations in stratified, frontal and tidally mixed shelf waters. Mar. Ecol. Progr. Ser. 17: 201-213.

Holmes, R. W., Schaefer, M. B. and Shimada, B. M. 1957: Primary production, cholorophyll, and zooplankton volumes in the tropical eastern Pacific Ocean. Bull. Inter-Am. Trop Tuna Comm. 2: 129-169. 
Judkins, D. C. 1980: Vertical distribution of zooplankton in relation to the oxygen minimum off Peru. Deep-Sea Research 27: 475-486.

Kirk, N. H. 1969: Some thoughts on the ecology, mode of life and evolution of the Graptolithina. Proceed., Geol. Soc. London, 1659: 273-292.

Kirk, N. H. 1978: Mode of life of graptolites. Acta Palaeontologica Polonica 23: 533-555.

Kirk, N. H. 1980: Controlling factors in the evolution of the graptolites. Geol. Mag. 117: 277-284.

Kozlowski, R. 1948: Les graptolithes et quelques nouveaux groupes d'animaux du Tremadoc de la Pologne. Palaeontologia Polonica III: 1-235.

Longhurst, A. R. 1967: Vertical distribution of zooplankton in relation to the eastern Pacific oxygen minimum. Deep-Sea Res. 14: 51-63.

McGowan, J. A. 1971: Oceanic biogeography of the Pacific. In: Furnell, B. M. and Riedel, W. R. (eds.): The Micropalaeontology of the Oceans, Cambridge University Press, 3-74.

Menzies, R. T., George, R. Y. and Rowe, G. T. 1973: Abyssal Environments and Ecology of the world Oceans. WileyInterscience, New York, 488 p. (p. 145 picture of bottom off Peru).

Mullins, H. T., Thompson, J. B., McDougall, K. and Vercoutere, T. L. 1985: Oxygen minimum zone edge effects: evidence from the central California coastal upwelling system. Geol. 13: 491-494.

Munk, W. 1966: Abyssal Recipies. Deep-Sea Res. 13: 701-730.

Qasim, S. Z. 1982: Oceanography of the northern Arabian Sea. Deep-Sea Res. 29: 1041-1068.

Reid, J. L. 1962: On circulation, phosphate-phosphorous contents and zooplankton in the upper part of the Pacific Ocean. Limnol. Oceanogr. 7: 287-306.

Richards, F. A. 1965: Anoxic basins and fjords. In: Riley, J. P. and Skirrow, G. (eds.) Chemical Oceanography, 1st ed. Academic Press, New York, 1: 611-645.

Rickards, R. B. 1975: Paleoecology of the Graptolithina, an ex- tinct class of the phylum Hemichordata. Biology Review 50: $397-436$.

Ruedemann, R. 1947: Graptolites of North America. Geol. Soc. Am. Mem. 19: 1-652.

Shanks, A. L. and Trent, J. D. 1980: Marine snow: sinking rates and potential role in vertical flux. Deep-Sea Res. 27: 137-143.

Smayda, T. J. 1970: Suspension and sinking of phytoplankton in the sea. Oceanogr. Mar. Bio. Ann. Rev. 8: 353-414.

Störmer, L. 1933: A floating organ in Dictyonema. Norsk Geol. Tids. 13: 102-112.

Störmer, L. 1935: Additional remarks on the presence of a floating organ in Dictyonema flabelliforme. Norsk. Geol. Tids. 14: 316-318.

Stumm, W. and Morgan, J. J. 1970: Aquatic Chemistry. WileyInterscience, New York, $583 \mathrm{p}$.

Teal, J. M. and Carey, F. G. 1967: Respiration of a eupahausiid from the oxygen minimum layer. Limnol. Oceanogr. 12: 548-550.

Wilde, P. and W. B. N. Berry 1982: Progressive ventilation of the oceans - potential for return to anoxic conditions in the post-Paleozoic. In: Schlanger, S. O. and Cita, M. B. (eds.): Nature and origin of Cretaceous organic carbon-rich facies. Academic Press, London, 209-224.

Wilde, P. and W. B. N. Berry 1984: Destabilization of the oceanic density structure and its significance to marine "extinction" events. Palaeogeog. Palaeoclim. Palaeoecol. 48: 143-162.

Wooster, W. S. and Cromwell, T. 1958: An oceanographic description of the eastern tropical Pacific. Scripps Inst. Oceanogr. Bull. 7: 169-282.

Wyrtki, K. 1967: Circulation and water masses in the eastern equatorial Pacific Ocean. Internat. J. Ocean Limnol. 1: 117-147.

Youngbluth, M. J. 1975: The vertical distribution and diel migration of euphausiids in the central waters of the eastern South Pacific. Deep-Sea Res. 22: 519-536. 